\title{
Presentation of: GLEAN: Social Learning for Business Students
}

\author{
Susan Gautsch and Charla Griffy-Brown \\ Graziadio School of Business, Pepperdine University, \\ Malibu, CA, USA
}

\author{
susan.gautsch@pepperdine.edu; Charla.Brown@pepperdine.edu
}

NOTE: This is a presentation of a work that was published as Chapter 12 in Cheal, C., Coughlin, J., \& Moore, S. (2012). Transformation in teaching: Social media strategies in higher education. Santa Rosa, CA: Informing Science Press.

\begin{abstract}
At Pepperdine's Graziadio School of Business and Management, the educational focus is on equipping business students with real-world experiential learning to immediately be more effective business practitioners. For this analysis we will focus on two classes. These classes are focused on preparing students to enhance processes and operations while strategically using information systems to remain competitive. Like most courses taught in the business school, these courses are driven by a series of case studies and a team-based project involving real-life clients with real business needs. Given both the professional nature of the business school and the geographic distribution of our five campuses across Southern and Northern California, many classes and programs are enhanced by the integration of e-learning pedagogies and tools. Specifically, the Graziadio Learning Environment and Network (GLEAN) is a "network of people and tools to learn, collaborate, and discover - bit by bit." Powered by Google Apps, GLEAN is a stable framework that integrates and uniformly authenticates our traditional learning systems with an ever-growing collection of Web2.0 and social media tools, including a Facebook-like social network called Yammer restricted to the Pepperdine domain. Here, we give a short orientation to the evolution of social networks followed by some theoretical and practical ways social networks enable new ways to learn, as well as some of the challenges. We then provide specific details about the class we both teach in a blended format, the specific assignments and activities, and concrete examples framed within each of the social and situated learning theories presented. We outline perceptions of social learning in this environment from both the professor's and students' perspective, then conclude with some implications for social and situated learning in the national imperative for a new "culture of evidence."

Of particular note in the conclusion is that the "culture of evidence" is an essential element of

Material published as part of this publication, either on-line or in print, is copyrighted by the Informing Science Institute. Permission to make digital or paper copy of part or all of these works for personal or classroom use is granted without fee provided that the copies are not made or distributed for profit or commercial advantage AND that copies 1) bear this notice in full and 2) give the full citation on the first page. It is permissible to abstract these works so long as credit is given. To copy in all other cases or to republish or to post on a server or to redistribute to lists requires specific permission and payment of a fee. Contact Publisher@InformingScience.org to request redistribution permission. using social media. Social media engenders the ability to apply outcomesbased rubrics and enables immediate feedback and adjustment of the learning process in a fully interactive and relational way. This feedback mechanism also teaches the process of knowledge management and constructivist learning which a business student will be using in their everyday business experience. Importantly, faculty can deliberately decide
\end{abstract}


how to enhance learning by explicitly considering what they are bringing, what the students are bringing and map this onto a desired process focused on specific learning outcomes. Not only does this social media process build learning capacity in the student, it is also highly measurable and feedback is immediate. Therefore, there aren't the attenuated feedbacks in the traditional learning process. This ongoing process informed by learner analytics as well as capacity building for the learner and the faculty is an active demonstration of $21^{\text {st }}$ century business practice and learning in a knowledge economy. The downside is the time-intensive nature of this process and also a new balancing of the "art" versus the "science" of teaching.

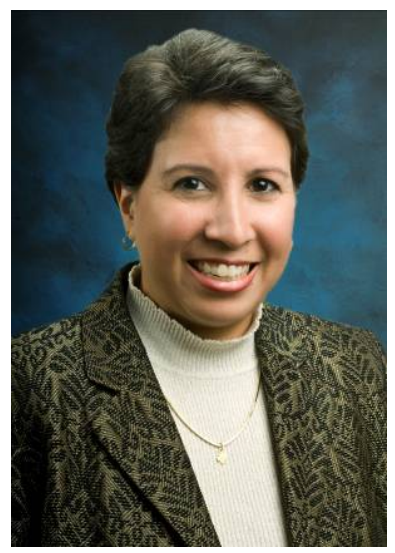

\section{Biographies}

Dr. Charla Griffy-Brown is currently Professor of Information Systems and Director of the Center for Teaching and Learning Excellence at Pepperdine University's Graziadio School of Business and Management. The Center for Teaching and Learning Excellence advances innovation in business education with e-learning as a key element of 21 st century learning. Dr. Griffy-Brown has co-authored a number of articles and white papers on digital technologies in education. In 2004, she received a research award from the International Association for the Management of Technology, which recognized her as one of the most active and prolific researchers in the Technology Management and Innovation field. Her research on information systems, innovation and new value creation for the public and private sectors was recognized in 2011 with a best paper award at the International Conference on Services Management held in New Dehli, India. A former researcher at the Foundation for Advanced Studies on International Development, Tokyo, Dr. Griffy-Brown has also served as an associate professor at the Tokyo Institute of Technology. Dr. Griffy-Brown graduated from Harvard University, is a former Fulbright Scholar, and holds a Ph.D. in Technology Management from Griffith University in Queensland, Australia. Her research has been funded by a Denny Endowment, an SAP University Alliance Grant, the Rothschild Research Endowment, and the Graziadio School of Business Funds for Excellence. She has conducted research and worked with public and private sector organizations throughout the US and the Asia-Pacific region including Indonesia, China, India, Japan and Australia. She has conducted research with companies such as Qwest, Honda, Hilton Hotels, Pratt-Whitney Rocketdyne/Boeing, Hitachi, Fujitsu and Canon. 